\title{
Status of North Kosovo from a Legal and Economic Perspective
}

\author{
Attila Nagy \\ Lecturer of Law and Public Administration \\ International Business College Mitrovica \\ North Kosovo, Mitrovica region
}

\section{Doi:10.5901/mjss.2013.v4n10p175}

\begin{abstract}
In this Interdisciplinary work we will deal with the Legal and Economic status of the North Kosovo region which has a very unique status and since recently its gaining more attention. It is even more interesting if we know that this small region has a very important role in European Union (hereinafter EU) politics as well. We will focus on the long debated questions for which not just the two countries Serbia and Kosovo, can't reach an agreement, but the EU and other International actors also have unclear and different opinions. For this region it is very hard to find relevant and applicable rules, since rules which could be applied have either no real power or could not be enforced. Applicable laws are the ones of Serbia and Kosovo but enforcement power is in the hands of European Union made body, EULEX (European Union Rule of Law Mission) (EulexKosovo), so how it is possible that such a strong political body like the EU can't enforce them? From an Economic and Finance perspective we will deal with the questions which are of tremendous importance not just for the people from the region but as well for Serbia, Kosovo, EU and the International community. It has to be outlined that even after reaching some Agreements between the Serbian and Kosovo governments, like the one from 19th April 2013 (1) (2) many important questions still lay unanswered and untouched. The most important questions are the ones related to enforcement, rule of law, social welfare, taxes and security. The pressure is now with the Agreement transferred from EULEX (Mission) to the Governments of Serbia and Kosovo. As professionals we have to approach these issues with no biases and as reasonably as possible also we have to focus on the on field situation and facts which are of crucial importance for anything what is happening and can happen.
\end{abstract}

\section{Prologue}

Before we approach such a complex problem which was and still is a widely debated problem in local and international community, it is necessary to say and also approach it from an unbiased and neutral position. The author of this work has no connections neither has been instructed by any of the parties involved, the author is absolutely independent and applies laws, regulations and other relevant documents to the problems present on the field. The author has lived in the divided city of Kosovska Mitrovica/Mitrovica and has a broad understanding and experience about the issues and factual situations happening in the City of Mitrovica, Kosovo and Serbia.

\section{Introduction}

As of April 2013 with the new Agreement (1) (2) between Serbia and Kosovo the status of the so called North Kosovo region became very specific in the sense of its legal status. In this work we are not discussing the previous legal statuses of Kosovo which were also specific in the legal sense but we are trying to define North Kosovo future status and that way predict and advice for the future and also encourage economic activities. From the date when the Agreement will be implemented the four North Kosovo municipalities which all have a Serbian majority will be affected by it. Namely these municipalities are Leposavic, Zvecan, Zubin Potok and the North part of the divided city of the once well known Kosovska Mitrovica (Tito Mitrovica). These Municipalities live under Serbian law and behave as they are part of Serbia. Both the Serbian and Kosovo sides claim that the region would develop under their rule, but how to trust them when their governments don't have so shiny examples. The International Community is also implementing and presenting some very successful economic success as examples, but they are usually short living and last as long as the big funds and donations don't get depleted. People need real development and work places where from they can plan their future. But it is not easy to do business without having an environment for that. Economic development is not possible if we have a very unclear legal background, unfortunately the de facto situation which is right now present on North Kosovo does not encourage economic activities. The most problematic field is rule of law and also serious improvements are needed to battle the following problems: corruption, nepotism, property rights, human and minority rights, safety and many other 
problems which are connected to the lack of state authority. But which state will guarantee basic rights to the citizens when we know that Serbia is not allowed to do so and Kosovo is not allowed to do so as North Kosovo citizens boycott its institutions.

\section{The effects of justice and law on life and economy}

As of the times when the first states were established the humans were trying and struggling to establish and organize them in a way which fits them the best. As they were experimenting in one moment they have found that some order, rules and law have to be accepted and respected. In order to guarantee a certain level of order and also guarantee justice and the same outcome in same situations. But since ancient times until today it was hard to apply law to each complicated factual situation of everyday life. That is why we have judges, arbitrators and other professionals who are able to apply law to the problems people have in everyday life. Once we have a decision we have to enforce it, but who is going to enforce a decision made by a judge. How can one person rule and then make two confronted parties accept its ruling. How to make divided people learn the lesson from their dispute. Even more what if a party thinks that the solution reached is unjust and not fair at all. As an example we can take the case which happened in an ancient state which was at that time ruled by a powerful and just king named Solomon. When two women came to him and asked to make justice in their dispute, which was about who is the mother of a recently born baby. The king made justice by telling them that since there can be only one mother to a baby and since they both claim them it would be just to split the baby into two parts so each of them will get an equal part of the baby. In that moment one of the ladies blessed the king and his wisdom and just decision where the other woman begged him not to do so. She asked him to change his just decision and just give the baby to the other woman. When King Solomon heard this he knew that this lady is the true mother of the child, since only mother would give up everything in order to know that her offspring will live and be safe (Bible). But what to do and how to survive the terrible moments of injustice when we know that something bad is happening or could happen to us. There is no unique formula or advice. Since as people say: "Little knows the fat man what the lean man thinks". How injustice feels and how hard it is to understand it and measure it. The same problem applies when we try to compensate for losses. How can a loss of a certain thing and feeling be compensated today. Usually loss is compensated by a sum of money. In law we can find criteria to determine the value of certain things and harms, but are they just and able to compensate. We can use a case which has happened many centuries ago where a Caliph met an Imam mending his shoes. When the Caliph asked him how much are they worth he said "Nothing". Caliph was surprised but the Imam explained, the same shoe has no value for the authority but it does have a value to its owner (Islam). It is clear from this case how people value things differently and how hard it is to value a loss which someone can encounter. From this introduction and cases we see how the decisions made by the authority influence the life and everyday activities of people. Since the well being of people is the most important and ultimate task of every state, which is achieved by applying Democratic principles, we need to see where democracy fails in a certain state or wider and how it influences the life of people and their economic activities.

\section{The actual situation of Law and Politics in North Kosovo}

As of 2013 the situation is rapidly changing in the city of North Mitrovica. As the unofficial capital the changes, losses and gains in this city are immediately reflected to other areas and citizens on North Kosovo. 
Picture 1: Kosovo with the Serbian Municipalities and North Mitrovica which is cut out from the Municipality of South Mitrovica by the river Ibar

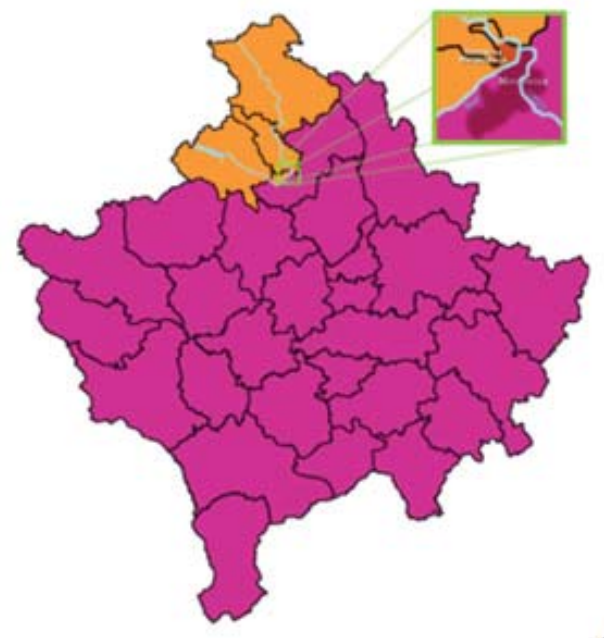

(Demographics)

North Mitrovica has a completely different and separate municipality run by Serbs as opposed to the South Mitrovica municipality. Since the new Kosovo Government run North Mitrovica municipal building started to operate successfully the employees of Serbian nationality in this institution were market by some people as traitors and were targeted. During a certain period of time they were attacked by many means usually by dropping a hand grenade into their yards. This was made according to the same unwritten rules which prohibit cars with Kosovo plates on the North Kosovo and bans all Kosovo state insignia. A noticeable exception is Kosovo Police which is bearing Kosovo insignia. They are tolerated but only because they are of Serbian nationality and have in fact no real power to prosecute or punish. Unfortunately because of this reason no one is protected by them and no one is expecting any help from them. Since the EULEX and Kosovo state have no other solutions to solve this long lasting status quo they started to put pressure on the Serbian Government to apply certain norms and achieve certain outcomes on the field and guarantee for them via International Agreements. Serbia is the only power which can change this situation since Serbia is financing all North Kosovo institutions and supports it by many means. It is easy to conclude that no state, city or individual can exist if it has no revenue and financing. We have to note that on North no taxes are paid or any kind of contribution to any state. Even electricity and water bills are not being paid and these resources are provided for free which is a very big cost for the provider. There is no executive power which could be able to proceed and ensure payments, as we noted police is just formally present. Courts are using Serbian law and apart from making decisions have no executive power on the North which would assist them since Kosovo police would not comply with Serbian court orders. On the other hand Kosovo courts even by having a mandate are prevented to do so since the citizens do not recognize them and massively boycott. Now since all of these issues are important for every state they were covered during the talks between Serbia and Kosovo and some solutions we can find in the April $19^{\text {th }} 2013$ Agreement (1) (2)

\section{Today, tomorrow and into the unknown future}

In this moment EULEX has a mandate until 14th June 2014 (Council). It is present in Kosovo since 2008 (Action) and has inherited this responsible work from the UNMIK. The basic legal document upon which the International Administration acquired its mandate is The UN Security Council Resolution 1244 (1999) (NATO) (Resolution). The main tasks these International organizations have on Kosovo are Rule of law tasks and enforcement duties. By now they have worked for almost 14 years and achieved different stages and levels of successes and improvements in Kosovo. Unfortunately there is very little they can be proud of in North Kosovo. Recently EULEX started do spread leaflets stating how hard it is to work in such an environment. It is very disappointing for citizens and people who have trust in the rule of law if a body or organization is trying to find excuses instead of improving its work by using its mandate. The most visible fail is for sure North Kosovo and with the April Agreement EULEX will be relieved from its mistakes by blaming someone else. Now we 
will focus and discuss what improvements and solutions are possible as per the Agreement. One of the main obstacles during negotiations and the biggest success of the Serbian side is that there will be a Regional Police Commander for the North who will be of Serbian nationality. Also the Serbian side agreed that they will not influence, what means pay, individuals on the North for performing Security tasks. Police on the North will be paid by Kosovo and that way their compliance with Kosovo laws will be ensured. By the specific Police and enforcement structure North is recognized as a separate political structure by stating that it is an Association/Community of Serb majority municipalities in Kosovo. This unclear definition is still to be explained since contracting parties understand it and explain it in different ways. In this work we will not deal with this problem since we don't have enough valuable data and the importance of this definition is very big and important in the international and domestic law. Courts will be also integrated into the Kosovo system, apply Kosovo law and issue documents according to it. A specific appellate division will be established for the North which will deal with the cases from the northern Serbian Municipalities. In this solution there is one very important outstanding problem, namely who will deal with the problems between Kosovo Albanians and Kosovo Serbs which have caused the biggest problems earlier. When we discuss the Mandatory elections to be held in 2013 for Northern Municipalities we have to come to a conclusion that pretty much the same parties and persons will be represented as now. The success of the elections and the number of voters will be influenced by the political situation prior to election days. Energy and Telecommunication issues had to be agreed within a very short time period, until $15^{\text {th }}$ of June. Since there are many problems in this regard it is visible how the EU does not understand the real life problems which go back to the Socialist times some 20 years ago. Serbia itself has not solved such problems and accordingly has no applicable solutions for the territory of North Kosovo.

\section{Conclusion}

The International presence in Kosovo is not that important anymore but its presence on North Kosovo is still vital. The only neutral power which is able to balance between the North and South prevent revenge and conflicts are the International Peacekeepers. The outcome of the April Agreement is somewhat influenced by the fear from the EU that if Serbs start leaving North Kosovo it will be a final knock down to International efforts of peacekeeping. Still the major role in achieving this Agreement was the promise made by EU to Serbia that after signing, agreeing and implementing this agreement they will be given the date to start Accession negotiations to join EU. The exact date is still pending, we are of the opinion that the key is still hidden somewhere on North Kosovo. More clearly on the main bridge in Kosovska Mitrovica which is blocked by a huge barricade which symbolizes the border and protects the citizens of the North from Kosovo institutions. The removal of this barricade will in turn open the gates of EU to Serbia but at what cost for North Kosovo. The future will show the value of this bridge barricade which is a state, nation and cultural border. 